\title{
Gingival phenotypes and their relation to age, gender and other risk factors
}

Wadhah Abdulnasser Alhajj ${ }^{1,2}$

\begin{abstract}
Background: Careful consideration and assessment of the type of phenotype has gained a fundamental importance in the treatment planning for any patient. We evaluated the prevalence of gingival phenotypes in a sample of Yemeni population and to explore its relationships to gender, age and other risk factors.

Methods: This cross-sectional study was performed among 456 patients. All maxillary anterior teeth were included for all parameters and 1st molars were included for gingival thickness measurements. All patients included in this study were systemically healthy and presented no dental crowding. Four clinical parameters were systematically recorded: Gingival thickness (GT), Width of keratinized gingiva (WKG), Crown width/ crown length (CW/CL) ratio and Papilla height (PH). Scores obtained from different parameters measurements were recorded and analyzed using nonparametric tests where $P$-value $<0.05$ was considered significant. One examiner performed all measurements.
\end{abstract}

Results: The mean age was $29.9 \pm 8.26$ years. Of 456 recruited subjects, 83 (18.2\%) subjects had thin, 69 (15.1\%) had thick GT and $304(66.7 \%)$ were placed in non-categorized $(1.5-2 \mathrm{~mm})$ GT. Square crown shape was found in 210 (44.1\%) patients and 245 patients (55.9\%) showed rectangular shape. Regarding WKG, 114 (25\%) patients had width $<4 \mathrm{~mm}, 319(70 \%)$ had width $4.1-8 \mathrm{~mm}$ and $23(5 \%)$ patients had width $>8 \mathrm{~mm}$. There was no significant difference between males and females for GT measurements. Regarding WKG, results showed that the prevalence of WKG 4.1-8 $\mathrm{mm}$ was more among females while males had more prevalence of $\leq 4 \mathrm{~mm}$ with significance difference. PH showed no significant differences between males and females. Regarding age, there was no significant differences between patients $\leq 25$ years and $>25$ years for all gingival parameters measurements. The relationship of smoking with different gingival parameters also showed no significant differences between smokers and non-smokers. Similarly, relationship of khat chewing with different gingival parameters showed no significant difference. Regarding inter-relationship between parameters, thin GT was associated with rectangular tooth form while square and quadrate forms are more associated with " $1.5-2 \mathrm{~mm}$ " GT. WKG of $\leq 4 \mathrm{~mm}$ was associated with rectangular tooth form while WKG > 8 was more associated with square and quadrate forms with no significant difference. Results showed significant association between thin GT with 4.1-8 mm WKG.

Conclusion: Yemeni population had more prevalence of "1.5-2 mm" GT, rectangular crown shape and WKG from 4.1-8 $\mathrm{mm}$. Regarding interrelationship between gingival parameters, GT showed obvious relationship with WKG, CW/CL ratio and PH. WKG with CW/CL also showed significant relationship while no relationship was shown between other gingival phenotype parameters.

Keywords: Phenotype, Gingiva, Keratinized, Papilla, Yemeni

\footnotetext{
Correspondence: waddah.alhaj@gmail.com

'Department of Periodontics, Faculty of Dentistry, Thamar University,

Dhamar, Yemen

${ }^{2}$ Department of Dentistry, Faculty of Medical sciences, Civilization University,

Sana'a, Yemen
}

\section{$\triangle B M C$}

(c) The Author(s). 2020 Open Access This article is licensed under a Creative Commons Attribution 4.0 International License, which permits use, sharing, adaptation, distribution and reproduction in any medium or format, as long as you give appropriate credit to the original author(s) and the source, provide a link to the Creative Commons licence, and indicate if changes were made. The images or other third party material in this article are included in the article's Creative Commons licence, unless indicated otherwise in a credit line to the material. If material is not included in the article's Creative Commons licence and your intended use is not permitted by statutory regulation or exceeds the permitted use, you will need to obtain permission directly from the copyright holder. To view a copy of this licence, visit http://creativecommons.org/licenses/by/4.0/. The Creative Commons Public Domain Dedication waiver (http://creativecommons.org/publicdomain/zero/1.0/) applies to the data made available in this article, unless otherwise stated in a credit line to the data. 


\section{Background}

In 1969, Ochsenbein and Ross documented that two major kinds of gingiva morphology, named as: scalloped and thin or flat and thick gingiva [1]. Subsequently, the term "periodontal biotype" was advanced by Seibert and Lindhe to classify the gingiva into "thick-flat" and "thinscalloped" biotypes [2]. Claffey and Shanley defined the thin tissue biotype as a GT of $<1.5 \mathrm{~mm}$, and the thick tissue biotype was referred to as having a tissue thickness $\pm 2 \mathrm{~mm}$ (measurements of 1.6 to $1.9 \mathrm{~mm}$ were not accounted for) [3]. These gingival types could be recognized with a slightly scalloped gingival margin, short and wide teeth on the one hand and a thin, highly scalloped gingival margin with slender teeth on the other. In the World Workshop on the Classification of Periodontal and Peri-Implant Diseases and the term periodontal biotype was replaced by periodontal phenotype [4]. In clinical practice, the identification of the gingival phenotype is considered important because differences in gingival and osseous architecture have been shown to exhibit a significant impact on the outcome of restorative therapy [5]. Gingival phenotype back to a collection of four characteristics of the soft tissues and the teeth they surround that build up to a particular picture. These are: 1. GT (thick or thin): The tissue thickness in a bucco-palatal dimension. 2. The gingival width (width of keratinized tissue WKG: Which indicated the width of the keratinized tissue when measured from the gingival margin to the muco-gingival junction. 3. Papilla height $(\mathrm{PH})$ /proportion: The gingival part that fits between teeth. 4. Crown width/ height ratio CW/CL: Long, slender teeth tend to be associated with contact points away from the alveolar crest and long papillae that fill the embrasures [6].

Many methods were proposed to measure tissue thickness. These include direct measurements, probe transparency [7], ultrasonic devices [8], and, most recently, cone-beam computed tomography (CBCT) [8]. In the direct method, the tissue thickness was measured using a periodontal probe [7]. When the thickness was \pm $1.5 \mathrm{~mm}$, it was categorized as a thick phenotype. When the thickness was $<1.5 \mathrm{~mm}$, it was considered a thin tissue phenotype. The width of attached gingiva varies from tooth to tooth and also among individuals with mixed opinions regarding an "adequate" or "sufficient" dimension of the gingiva. Although the need for a so-called adequate amount of keratinized tissue for maintenance of periodontal health is questionable, the mucogingival junction serves as an important clinical landmark in periodontal evaluation. There are various methods of locating the mucogingival junction namely the functional method and the visual method with and without histochemical staining, which aid in the measurement of the width of attached gingiva [9].

Tissue phenotype are related to the response of the periodontal tissues to any physical, chemical, or bacterial insult, outcome of restorative, periodontal therapy, root coverage procedures, and overall esthetics of a dentition. Careful consideration and assessment of the type of phenotype has gained a fundamental importance in the treatment planning for any patient. Hence, it is important to gain knowledge about the prevalence of gingival phenotype in the general population and its relationship with other known clinical parameters [10]. The aims of this study was to evaluate the prevalence of gingival phenotypes in a sample of Yemeni population and assess its relationship to gender, age, smoking and khat chewing and other risk factors. This study also aimed to evaluate the interrelationship between the parameters of gingival phenotype.

\section{Methods}

A Qualtrics ${ }^{\mathrm{XM}}$ sample size calculator was used to calculate the sample size based on the population size of the surveyed area. The power was calculated to be $95 \%$ using marginal error of 0.05 . The total population size was considered as three millions which is the approximate enumeration of Sana'a city which is the site of our study. A total of 456 subjects were required for this study. Subjects were selected from a private clinic in Sana'a city. Each patient attended the clinic and coinciding the inclusion criteria was enrolled in the study. This research was approved by the ethics committee at Thamar University (Faculty of Dentistry) with a reference number (2019002). All maxillary anterior teeth were included for all parameters and 1st molars were included for GT measurements. All patients included in this study were systemically healthy and presented no dental crowding. The exclusion criteria were: (i) subjects with a mouth breathing habit (ii) subjects with crown restorations or fillings involving the incisal edge on anterior maxillary teeth, (iii) those with any removable device such as a removable partial denture, or removable orthodontic retainer, (iv) missing any of the six maxillary anterior teeth and having Millers Class III or Class IV recession (v) pregnant or lactating females and (vi) subjects taking medications with any known effect on the periodontal soft tissues $[11,12]$. All subjects were provided with oral hygiene instructions and tooth polishing. This was preceded by calculus removal, if necessary. Witten informed consents were obtained from study participants.

\section{Clinical parameters}

Four clinical parameters were systematically recorded by a single clinician 2 weeks following oral hygiene instructions and dental cleaning:-

a) Gingival thickness (GT) was evaluated and categorized into thick or thin. This evaluation was 
based on direct measurements according to Seibert and Lindhe [2]. According to this classification, thickness between $(1.5-2 \mathrm{~mm})$ is not-categorized. The gingiva was anesthetized by topical-application of an anesthetic gel. An endodontic spreader size 15 with a rubber stop/caliper was inserted at a point at the center of the gingival margin and mucogingival junction in a perpendicular direction (Fig. 1) and this measurement was recorded with periodontal probe (Fig. 2) [13]. The thickness of the attached gingiva was recorded for upper right central incisor, upper left lateral incisor, upper right 1st molar, lower right 1st molar, upper left 1st molar and lower left 1st molar. The final readings for maxillary and mandibular GT were obtained by calculating the mean of all six measurements [14].

b) Width of keratinized gingiva (WKG) was measured mid-facially to the nearest $0.5 \mathrm{~mm}$ according to Fischer et al. [15] with a periodontal probe (UNC 12) (Fig. 3). This parameter is defined as the distance from the free gingival margin to the mucogingival junction. So, we measured the keratinized gingival width from the gingival margin in the most apical point of the margin to mucogingival margin.

c) Papilla height $(\mathrm{PH})$ was assessed to the nearest 0.5 $\mathrm{mm}$ Fischer et al. [15] using the same periodontal probe at the mesial and the distal aspect of both central and lateral incisors (Fig. 4). This parameter is defined as the distance from the top of the papilla to a line connecting the mid-facial soft tissue margin of the two adjacent teeth [16]. The mean value was calculated for the five measured papillae.

d) Crown width/crown length $(\mathrm{CW} / \mathrm{CL})$ ratio of the right central incisor was determined according to Olsson E Lindhe [16]. Assessments of width and length were recorded to the nearest $0.5 \mathrm{~mm}$ Fischer et al. [15] using a periodontal probe (Fig. 5). The

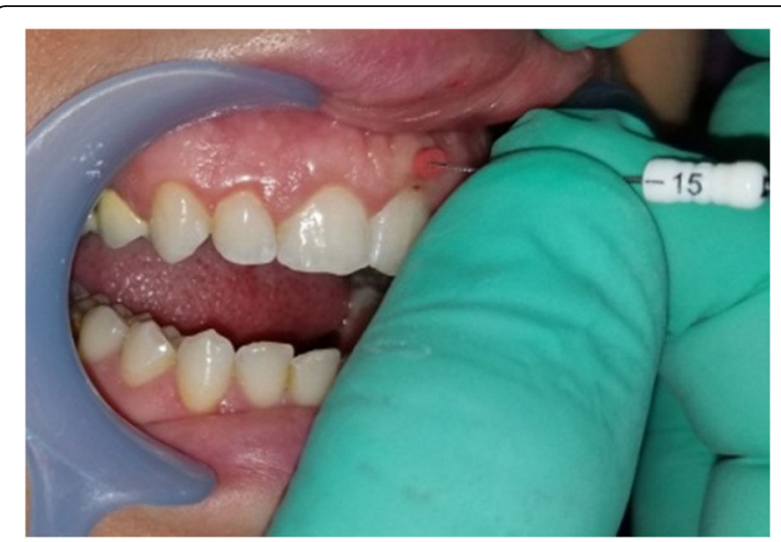

Fig. 1 Measurement of GT with endodontic spreader No 15

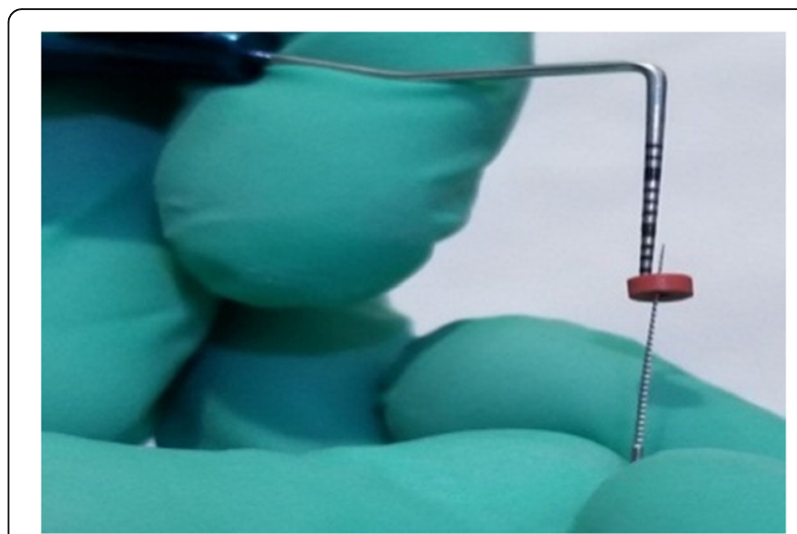

Fig. 2 Measurement of penetration of gingiva with periodontal probe

crown length was measured between the incisal edge of the crown and the free gingival margin, or if discernible, the cemento-enamel junction. Crown width, i.e. the distance between the proximal tooth surfaces, was recorded at the border between the middle and the cervical portion.

As a ratio of 80:100 seems to be ideal, a CW/CL above $80 \%$ may be regarded as broad square and below as narrow

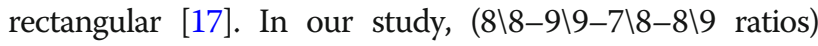
were considered as square or quadrate and (8\10-7\9-7.5 19-8 111) ratios were considered as rectangular. Scores obtained from measures of different parameters were recorded and averaged errors were minimized by allowing only one examiner to perform all the measurements.

\section{Statistical analysis}

Descriptive statistics were performed in terms of means, frequencies, and percentages for study variables. Nonparametric Chi-Squared test was used for the association between the study variables. Contingency Chi-Squared test was used for variables with more than 2 categories.

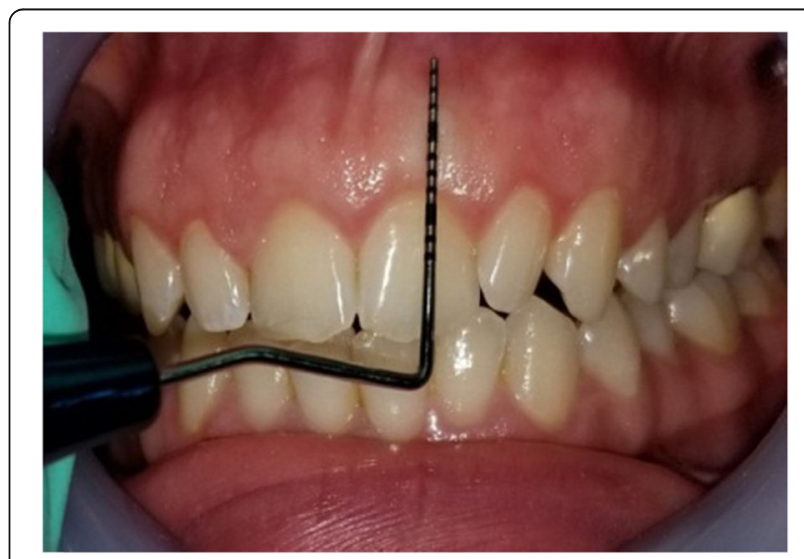

Fig. 3 Measurement of WKG 


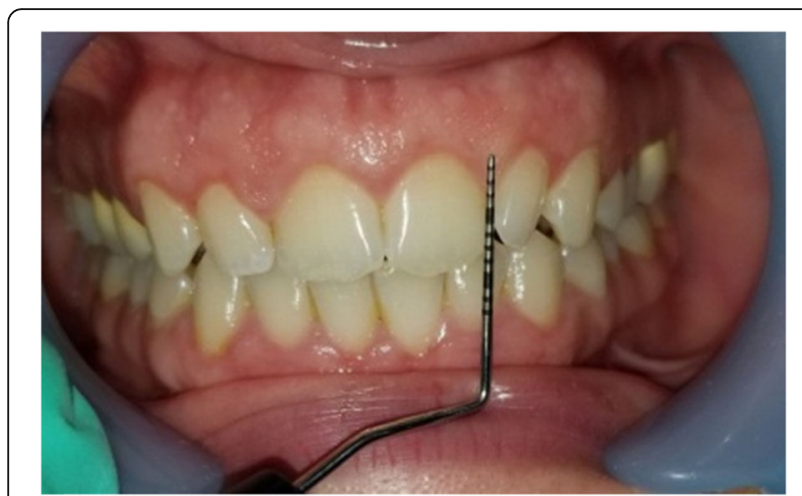

Fig. 4 Measurement of PH

$P$-value less than 0.05 was considered significant for all tests. The Computer program software SPSS V22 for Windows was used for data analysis.

\section{Results}

The mean age of the study population was $29.9 \pm 8.26$ years. Of the total 456 subjects, there were 215 (47.2\%) males and $241(52.8 \%)$ females; 83 (18.2\%) subjects had thin GT, 69 (15.1\%) had thick GT and 304 (66.7\%) were present in non-categorized $(1.5-2 \mathrm{~mm})$ thickness. 210 (44.1\%) patients demonstrated square or quadrate crown shape and 245 (55.9\%) showed rectangular shape. Regarding WKG, 114 (25\%) patients had width $<4 \mathrm{~mm}$, 319 (70\%) had width 4.1-8 mm and 23 (5\%) patients had width $>8 \mathrm{~mm}$. More details were shown in Table 1. All parameters showed no significant difference between the measured teeth. Table 2 shows the relationship of gender and age groups with different gingival parameters. There was no significant difference between males and females for GT and PH measurements while WKG results showed more prevalence of WKG 4.1-8 $\mathrm{mm}$ in females and males had prevalence of $\leq 4 \mathrm{~mm}$ with

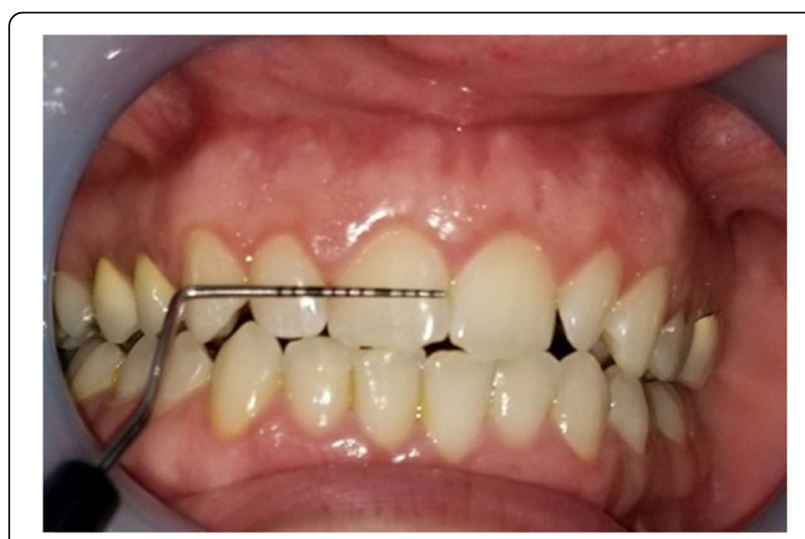

Fig. 5 Measurement of crown width
Table 1 Characteristics of the study sample

\begin{tabular}{|c|c|c|}
\hline Parameters & Frequency & $\%$ \\
\hline \multicolumn{3}{|l|}{ Gender } \\
\hline Male & 215 & 47.2 \\
\hline Female & 241 & 52.8 \\
\hline \multicolumn{3}{|l|}{ Age } \\
\hline$\leq 25$ years & 154 & 33.8 \\
\hline$>25$ years & 302 & 66.2 \\
\hline \multicolumn{3}{|l|}{ Smoking } \\
\hline Yes & 132 & 28.9 \\
\hline No & 324 & 71.1 \\
\hline \multicolumn{3}{|l|}{ Duration } \\
\hline$<5$ years & 61 & 46.2 \\
\hline$\geq 5$ years & 71 & 53.8 \\
\hline \multicolumn{3}{|l|}{ Khat chewing } \\
\hline Yes & 221 & 48.5 \\
\hline No & 235 & 51.5 \\
\hline \multicolumn{3}{|l|}{ Duration } \\
\hline$<5$ years & 76 & 34.4 \\
\hline$\geq 5$ years & 145 & 65.6 \\
\hline \multicolumn{3}{|l|}{ Gingival thickness } \\
\hline$<1.5 \mathrm{~mm}$ & 83 & 18.2 \\
\hline $1.5-2 \mathrm{~mm}$ & 304 & 66.7 \\
\hline$>2 \mathrm{~mm}$ & 69 & 15.1 \\
\hline \multicolumn{3}{|l|}{ CW/CL Ratio } \\
\hline Square/quadrate & 210 & 44.1 \\
\hline Rectangular & 246 & 55.9 \\
\hline \multicolumn{3}{|c|}{ Width of keratinized gingiva } \\
\hline$\leq 4 \mathrm{~mm}$ & 114 & 25 \\
\hline $4.1-8 \mathrm{~mm}$ & 319 & 70 \\
\hline$>8 \mathrm{~mm}$ & 23 & 5 \\
\hline \multicolumn{3}{|l|}{ Papilla height } \\
\hline$\leq 3 \mathrm{~mm}$ & 250 & 54.8 \\
\hline$>3 \mathrm{~mm}$ & 206 & 45.2 \\
\hline
\end{tabular}

significance difference $(P=0.006)$. Regarding the relationship of age groups with different gingival parameters, there was no significant differences between patients $\leq 25$ years and $>25$ years for all gingival parameters. Relationship of smoking with different gingiva parameters also showed no significant difference between smokers and non-smokers. Duration of the smoking appeared as an important factor in GT measurements. Smoking with duration less than 5 years are more associated with thin GT while smoking more than 5 years showed more association with (1.5-2.0 mm) GT with significant difference. WKG and PH showed no significant difference between two groups (Table 3 ). The relationship of khat chewing 
Table 2 Comparison between both genders and age groups in relation to GT, WKG, and PH

\begin{tabular}{|c|c|c|c|c|c|c|c|}
\hline & & \multicolumn{2}{|l|}{ Gender } & \multirow[t]{2}{*}{$P$} & \multicolumn{2}{|l|}{ Age } & \multirow[t]{2}{*}{$P$} \\
\hline & & Male & Female & & $\leq 25$ years & $>25$ years & \\
\hline \multirow[t]{3}{*}{ GT } & $<1.5 \mathrm{~mm}$ & $28(13.0)$ & $56(23.2)$ & 0.347 & 29 (18.8) & $56(18.5)$ & 0.931 \\
\hline & $1.5-2 \mathrm{~mm}$ & 155 (72.2) & $149(61.8)$ & & $104(67.5)$ & 199 (65.9) & \\
\hline & $>2 \mathrm{~mm}$ & $32(14.8)$ & $36(15.0)$ & & $21(13.7)$ & 47 (15.6) & \\
\hline \multirow[t]{3}{*}{ WKG } & $\leq 4 \mathrm{~mm}$ & 81 (37.7) & $34(14.1)$ & $0.006^{*}$ & $25(16.2)$ & 87 (28.8) & 0.303 \\
\hline & $4.1-8 \mathrm{~mm}$ & $127(59.1)$ & 191 (79.3) & & $121(78.6)$ & $200(66.2)$ & \\
\hline & $>8 \mathrm{~mm}$ & $7(3.2)$ & $16(6.6)$ & & $8(5.2)$ & $15(5.0)$ & \\
\hline \multirow[t]{2}{*}{$\mathrm{PH}$} & $\leq 3 \mathrm{~mm}$ & 115 (53.5) & $133(55.2)$ & 0.891 & $97(63.0)$ & $152(50.3)$ & 0.186 \\
\hline & $>3 \mathrm{~mm}$ & $100(46.5)$ & $108(44.8)$ & & $57(37.0)$ & $150(49.7)$ & \\
\hline
\end{tabular}

with the different gingiva parameters also showed no significant differences between khat chewers and nonchewers in all parameters. Similarly, There were no significant differences between khat chewers $<5$ years and $\geq 5$ years for all gingival parameters (Table 4 ). The associations between the study variables are shown in Table 5. There was significant association between GT and WKG $(P=0.009)$, the results showed association between thin GT with $4.1-8 \mathrm{~mm}$ WKT. Also, significant association $(P<0.001)$ was shown between GT with $\mathrm{CW} / \mathrm{CL}$ Ratio. In this regard, thin GT was associated with rectangular tooth form while square and quadrate forms were more associated with "1.5- $2 \mathrm{~mm}$ " GT. The association between GT with PH showed worthwhile results which revealed that thin GT was obviously associated with $\mathrm{PH} \leq 3 \mathrm{~mm}$ and thick thickness was more associated with $\mathrm{PH}>3 \mathrm{~mm}$ with significant difference $(P=0.011)$. Regarding the association between CW/CL with WKG, thickness of $\leq 4 \mathrm{~mm}$ was associated with rectangular tooth form while thickness $>8 \mathrm{~mm}$ was more associated with square and quadrate forms with significant difference $(P=0.005)$. Finally, $\mathrm{PH}$ failed to show an association with WKG although all cases of $>8 \mathrm{~mm}$ WKG had PH $>3 \mathrm{~mm}$ but other classes did not show any associations $(P=0.559)$. Similarly, no significant association was noticed between $\mathrm{CW} / \mathrm{CL}$ with $\mathrm{PH}(P=0.117)$.

\section{Discussion}

The dimensions of gingiva and different parts of the masticatory mucosa demonstrate considerable site and subject variability. They have become the subject of considerable interest in restorative and periodontics from both an epidemiologic, as well as a therapeutic point of view [8]. In this study, the vast majority of cases had GT between $(1.5-2.0 \mathrm{~mm})$ with prevalence $66.7 \%$. Thin and thick gingivae represents less prevalence in Yemeni population. Thin GT requires special considerations during esthetic, restorative, and periodontal therapy. These results are not correspondent to Shah et al. [10] and Zawawi $K H$ et al. [18] who showed that thin GT was observed in 43.25 and $44.50 \%$ of the sample. These differences may be logical because they use different classifications. According to Kydd et al. [19], the average thickness of gingiva between lateral incisors and central incisors are slightly below $3 \mathrm{~mm}$ between premolars and molars slightly above $3 \mathrm{~mm}$. These results are different from the results of present study with $1.9 \mathrm{~mm}$ for incisors and $1.8 \mathrm{~mm}$ for molars. Shah et al. [10] and Egreja $A M$ et al. [13] recorded more convergent values with our study.

Regarding evaluation of the relationship of smoking and GT, our data revealed that non-smokers had more GT between $(1.5-2.0 \mathrm{~mm})$ while smokers had more

Table 3 Comparison between smokers and non-smokers and smoking duration in relation to GT, WKG, and PH

\begin{tabular}{|c|c|c|c|c|c|c|c|}
\hline & & \multicolumn{2}{|l|}{ Smoking } & \multirow[t]{2}{*}{$P$} & \multicolumn{2}{|c|}{ Smoking duration } & \multirow[t]{2}{*}{$P$} \\
\hline & & Yes & No & & $<5$ years & $\geq 5$ years & \\
\hline \multirow[t]{3}{*}{$\overline{\mathrm{GT}}$} & $<1.5 \mathrm{~mm}$ & $33(25.0)$ & $48(14.8)$ & 0.112 & $27(44.3)$ & $5(7.0)$ & $0.007^{*}$ \\
\hline & $1.5-2 \mathrm{~mm}$ & $68(51.5)$ & $236(72.8)$ & & $13(21.3)$ & $56(78.9)$ & \\
\hline & $>2 \mathrm{~mm}$ & $31(23.5)$ & $40(12.3)$ & & $21(34.4)$ & $10(14.1)$ & \\
\hline \multirow[t]{3}{*}{ WKG } & $\leq 4 \mathrm{~mm}$ & $23(17.4)$ & $93(28.7)$ & 0.246 & $4(6.6)$ & $19(26.8)$ & 0.354 \\
\hline & $4.1-8 \mathrm{~mm}$ & $95(72.0)$ & $219(67.6)$ & & $47(77.0)$ & $47(66.2)$ & \\
\hline & $>8 \mathrm{~mm}$ & $14(10.6)$ & $12(3.7)$ & & $10(16.4)$ & $5(7.0)$ & \\
\hline \multirow[t]{2}{*}{$\mathrm{PH}$} & $\leq 3 \mathrm{~mm}$ & $82(62.1)$ & $168(51.9)$ & 0.345 & $26(42.6)$ & $56(78.9)$ & 0.093 \\
\hline & $>3 \mathrm{~mm}$ & $50(37.9)$ & $156(48.1)$ & & $35(57.4)$ & $15(21.1)$ & \\
\hline
\end{tabular}


Table 4 Comparison between Khat chewers and non-chewers and Khat chewing duration in relation to GT, WKG, and PH

\begin{tabular}{|c|c|c|c|c|c|c|c|}
\hline & & \multicolumn{2}{|c|}{ Khat chewing } & \multirow[t]{2}{*}{$P$} & \multicolumn{2}{|c|}{ khat chewing duration } & \multirow[t]{2}{*}{$P$} \\
\hline & & Yes & No & & $<5$ years & $\geq 5$ years & \\
\hline \multirow[t]{3}{*}{$\overline{\mathrm{GT}}$} & $<1.5 \mathrm{~mm}$ & $34(15.1)$ & 46 (19.6) & 0.803 & $13(17.1)$ & $21(14.5)$ & 0.719 \\
\hline & $1.5-2 \mathrm{~mm}$ & $149(67.9)$ & $156(66.4)$ & & $55(72.4)$ & $95(65.5)$ & \\
\hline & $>2 \mathrm{~mm}$ & $38(17.0)$ & $33(14.0)$ & & $8(10.5)$ & $29(20.0)$ & \\
\hline \multirow[t]{3}{*}{ WKG } & $\leq 4 \mathrm{~mm}$ & $66(30.2)$ & $50(21.2)$ & 0.084 & $34(44.7)$ & $34(23.5)$ & 0.259 \\
\hline & $4.1-8 \mathrm{~mm}$ & $134(60.4)$ & $181(77.0)$ & & $38(50.0)$ & $95(65.5)$ & \\
\hline & $>8 \mathrm{~mm}$ & $21(9.4)$ & $4(1.8)$ & & $4(5.3)$ & $16(11.0)$ & \\
\hline \multirow[t]{2}{*}{$\mathrm{PH}$} & $\leq 3 \mathrm{~mm}$ & $130(58.5)$ & $120(51.0)$ & 0.425 & $55(72.4)$ & $74(51.0)$ & 0.15 \\
\hline & $>3 \mathrm{~mm}$ & $91(41.5)$ & $115(49.0)$ & & $21(27.6)$ & $71(49.0)$ & \\
\hline
\end{tabular}

thick GT (>2 mm) but with no significant difference. Our results were correspondent to Zawawi $\mathrm{KH}$ et al [18] who have Only $31.4 \%$ of current smokers had thin GT. Our results showed that smoking with duration less than 5 years are more associated with thin GT while smoking more than 5 years showed more association with GT between $(1.5-2.0 \mathrm{~mm})$. To best to our knowledge, no documented studies discussed this topic. The relationship of GT with age was evaluated by Agarwal $V$. et al. [14] They observed that thickness of gingiva significantly decreased with age which contradicted the results of this study which showed that there is no difference in GT with age. Agarwal V. et al. [14] also studied the relationship of GT with gender and found that the thickness of

Table 5 Inter-associations between GT, WKG, and PH

\begin{tabular}{|c|c|c|c|c|}
\hline & & GT & & \\
\hline & $<1.5 \mathrm{~mm}$ & $1.5-2 \mathrm{~mm}$ & $>2 \mathrm{~mm}$ & $P$-Value \\
\hline \multicolumn{5}{|l|}{ WKG } \\
\hline$\leq 4 \mathrm{~mm}$ & $0(0.0)$ & $92(30.3)$ & $22(31.9)$ & \multirow[t]{3}{*}{$0.009^{*}$} \\
\hline $4.1-8 \mathrm{~mm}$ & $83(100.0)$ & $211(69.4)$ & $25(36.2)$ & \\
\hline$>8 \mathrm{~mm}$ & $0(0.0)$ & $1(0.3)$ & $22(31.9)$ & \\
\hline \multicolumn{5}{|l|}{$\mathrm{CW} / \mathrm{CL}$} \\
\hline Square/Quadrate & $0(0.0)$ & $187(89.0)$ & $23(11.0)$ & \multirow[t]{2}{*}{$<0.001^{*}$} \\
\hline Rectangular & $83(33.7)$ & $117(47.6)$ & $46(18.7)$ & \\
\hline \multicolumn{5}{|l|}{$\mathrm{PH}$} \\
\hline$\leq 3 \mathrm{~mm}$ & $61(73.5)$ & $168(55.3)$ & $21(30.4)$ & \multirow[t]{4}{*}{$0.011^{*}$} \\
\hline \multirow[t]{3}{*}{$>3 \mathrm{~mm}$} & $22(26.5)$ & $136(44.7)$ & 48 (71.6) & \\
\hline & & \multicolumn{2}{|l|}{ WKG } & \\
\hline & $\leq 4 \mathrm{~mm}$ & $4.1-8 \mathrm{~mm}$ & $>8 \mathrm{~mm}$ & \\
\hline \multicolumn{5}{|l|}{$\mathrm{CW} / \mathrm{CL}$} \\
\hline Square/Quadrate & $32(15.2)$ & $155(73.8)$ & $23(11.0)$ & \multirow[t]{2}{*}{$0.005^{*}$} \\
\hline Rectangular & $82(33.3)$ & $164(66.7)$ & $0(0.0)$ & \\
\hline \multicolumn{5}{|l|}{$\mathrm{PH}$} \\
\hline$\leq 3 \mathrm{~mm}$ & $58(50.9)$ & $192(60.2)$ & $0(0.0)$ & \multirow[t]{4}{*}{0.599} \\
\hline \multirow[t]{3}{*}{$>3 \mathrm{~mm}$} & $56(49.1)$ & $127(39.8)$ & $23(100.0)$ & \\
\hline & & \multicolumn{2}{|l|}{$\mathrm{CW} / \mathrm{CL}$} & \\
\hline & Square/Quadrate & & Rectangular & \\
\hline \multicolumn{5}{|l|}{$\mathrm{PH}$} \\
\hline$\leq 3 \mathrm{~mm}$ & $129(61.4)$ & & $121(48.4)$ & \multirow[t]{2}{*}{0.117} \\
\hline$>3 \mathrm{~mm}$ & $81(38.3)$ & & $125(51.6)$ & \\
\hline
\end{tabular}


gingiva significantly higher in females than males. Our results also disagreed with these results with males showed thicker GT than females. This contradiction may be due to ethinic differences where the mentioned study was done in India and this study was done in Yemen. Muller's, Wara-aswapati et al. [20] and Vandana and Savitha [21] studies agreed with us and supported that women have thinner gingivae than men [22]. Zawawi $\mathrm{KH}$ et al [18] also stated that thin GT represents $64 \%$ in females and $25 \%$ in males. De rouck also agreed with us as he observed that thin gingiva was found mainly in female with slender teeth. Also, he found that thick gingiva was found mainly in males which is not correspondent to us with approximately equal distribution between males and females [5].

Evaluation of WKG showed that most of Yemeni population are categorized in $4.1-8 \mathrm{~mm}$ group which considered as sufficient keratinized gingiva. Shah et al. [10] documented that the mean WKG of central incisor, lateral incisor, and canine in Group I was $4.38 \pm 1.18$, $5.18 \pm 1.25,4.16 \pm 1.16 \mathrm{~mm}$ respectively. This results were slightly less than our data with $5.0 \pm 1.50,5.9 \pm 1.60$ and $5.3 \pm 1.36$ for the same teeth but our data agreed with him in which WKG was the greatest for lateral incisor followed by central incisor and canine. When comparing this parameter between males and females, the results of the present study showed that females had more keratinized gingiva than males with significant difference. This may be in accordance to an explanation that stated that females were found to be twice as likely as males to have a gummy smile [22]. De rouck recorded that females had a narrow zone of keratinized tissue which contradicted our data [5]. Shah et al. [10] and Olsson et al. [16] also found a strong relationship between the WKG and GT which is correspondent to the results of present study. This finding further supports the notion that patients with a thin GT require a more careful treatment planning [10]. No relationship was found between WKG with age, where approximate keratinized gingiva where found in different age groups. This is conflicting with Ainamo A. et al. [23] who stated that there is a continuous growth through adult age of the basal bone with continuous widening of the band of attached gingiva in the male but not in the female cranium. This difference may be because in the mentioned study, the age was to 63 years old in contrary to 51 in this study. The crown form (CW/CL Ratio) in this study revealed that rectangular form of incisors are more prevalent than square or quadrant form in Yemeni population. Regarding the relationship of CW/CL Ratio with WKG, our results showed that the thickness of $\leq 4 \mathrm{~mm}$ is associated with rectangular tooth form while thickness $>8$ os more associated with square and quadrate forms. Olsson et al. [16] were not able to find a statistically significant difference in GT between thick and thin gingivae based on crown shape defined by $\mathrm{CW} / \mathrm{CL}$ ratio This is controversy to our results which demonstrated that rectangular shape is mostly associated with thin GT while square and quadrate shape are more associated with thick and (1.5-2.0 mm) GT.

Ochsenbein and Ross [1] believed that long-tapered teeth tend to have a thin-scalloped periodontium, whereas wide-square teeth have thick-flat periodontia. These results were correspondent to our data which showed that thin GT is associated with rectangular tooth form while square and quadrate forms are more associated with $(1.5-2.0 \mathrm{~mm})$ GT. Olsson et al. [7] contradict this and reported that no significant difference between narrow- and wide-crown forms with respect to the thickness of the free gingiva. Fischer stated that CW/CL is not a reliable parameter to assess the gingival phenotype, because according to the available data, there might be low and high scalloping, slender and broad teeth within one gingival phenotype [15]. In this study, the lengths of the interproximal dental papillae varied from 1 to $6 \mathrm{~mm}$, with most of them at 3-4 $\mathrm{mm}$ which in agreement with Chang [24, 25] and Chen MC et al. [26] and showed a negative relationship between age and papilla height. Those results was correspondent to this study, which revealed that age did not significantly influence the papilla height. They also showed that sex did not significantly influence the presence of the interproximal dental papilla or its length as our results did. Kan et al. [27] observed a significant higher interproximal tissue height in the thick GT group compared with the thin GT group. These results were convergent with our data which revealed that thin GT is obviously associated with $\mathrm{PH} \leq 3 \mathrm{~mm}$ and thick $\mathrm{GT}$ is more associated with $\mathrm{PH}>3 \mathrm{~mm}$ with significant difference. Olsson et al. [16] also found a relationship between PH and GT. Chen et al. [26] found that the length of the interproximal dental papilla was significantly related to the width of the keratinized gingiva. These results were in contradiction to our results which showed no obvious relationship between these parameters. Recently, Chow et al. discussed the appearance of gingival papillae in relation to crown shape and GT. They found that GT was positively correlated with interproximal tissue height and hence with papillae appearance [28]. We agreed with them as thin GT was obviously associated with $\mathrm{PH} \leq 3 \mathrm{~mm}$ and thick GT was more associated with $\mathrm{PH}>3 \mathrm{~mm}$ with significant difference.

\section{Conclusion}

It is concluded that Yemeni population has more prevalence of (1.5-2.0 mm) GT, rectangular crown shape and WKG from 4.1-8 mm. Regarding interrelationship between gingival parameters, GT showed strong relationship 
with WKG, (CW/CL) ratio and (PH). WKG with CW/CL Ratio also showed strong relationship while no relationship was shown between other gingival phenotype parameters. Studies with a heterogeneous population are needed to confirm the results presented in our study. Future research are needed to develop a more precise expanded and flexible classification system to classify and analyze gingival phenotypes parameters.

\section{Abbreviations}

GT: Gingival thickness; WKG: Width of keratinized gingiva; CW/CL: Crown width/ crown length ratio; PH: Papilla height

\section{Acknowledgements}

Not applicable.

\section{Authors' contributions}

The principal author designed the study, collected the data, and drafted the manuscript. The author(s) read and approved the final manuscript.

\section{Funding}

No funding.

\section{Availability of data and materials}

The datasets supporting the findings of this article are available from the corresponding author.

\section{Ethics approval and consent to participate}

The study was approved from Ethical committee at Thamar University (Faculty of Dentistry) and written informed consents were obtained from patients to participate.

\section{Consent for publication}

Not applicable.

\section{Competing interests}

The authors declare that they have no competing interests.

Received: 22 October 2019 Accepted: 11 March 2020

Published online: 25 March 2020

\section{References}

1. Ochsenbein C, Ross S. A reevaluation of osseous surgery. Dent Clin N Am. 1969;13(1):87.

2. Seibert J, Lindhe J. Esthetics and periodontal therapy. Textbook of Clinical Periodontology. 2nd ed. Copenhangen: Munksgaard; 1989. p. 477-514.

3. Claffey N, Shanley D. Relationship of gingival thickness and bleeding to loss of probing attachment in shallow sites following nonsurgical periodontal therapy. J Clin Periodontol. 1986:13(7):654-7.

4. Jepsen S, Caton JG, Albandar JM, Bissada NF, Bouchard P, Cortellini P, et al. Periodontal manifestations of systemic diseases and developmental and acquired conditions: consensus report of workgroup 3 of the 2017 world workshop on the classification of periodontal and Peri-implant diseases and conditions. J Clin Periodontol. 2018:45:S219-S29.

5. De Rouck T, Eghbali R, Collys K, De Bruyn H, Cosyn J. The gingival biotype revisited: transparency of the periodontal probe through the gingival margin as a method to discriminate thin from thick gingiva. J Clin Periodontol. 2009:36(5):428-33.

6. Sammut E. Soft tissue biotype and its implications-Dental Clinical Articles-PPD.

7. Greenberg J, Laster L, Listgarten M. Transgingival probing as a potential estimator of alveolar bone level. J Periodontol. 1976:47(9):514-7.

8. Müller HP, Heinecke A, Schaller N, Eger T. Masticatory mucosa in subjects with different periodontal phenotypes. J Clin Periodontol. 2000:27(9):621-6.

9. Bhatia G, Kumar A, Khatri M, Bansal M, Saxena S. Assessment of the width of attached gingiva using different methods in various age groups: a clinical study. J Indian Soc Periodontol. 2015;19(2):199.

10. Shah R, Sowmya N, Mehta D. Prevalence of gingival biotype and its relationship to clinical parameters. Contemp Clin Dent. 2015;6(Suppl 1):S167.
11. Miller P Jr. A classification of marginal tissue recession. Int J Periodont Rest Dent. 1985;5:9.

12. Eghbali A, De Rouck T, De Bruyn H, Cosyn J. The gingival biotype assessed by experienced and inexperienced clinicians. J Clin Periodontol. 2009;36(11): 958-63.

13. Medina Coeli Egreja A, Kahn S, Barceleiro M, Bittencourt S. Relationship between the width of the zone of keratinized tissue and thickness of gingival tissue in the anterior maxilla. Int J Periodontics Restorative Dent 2012:32(5):573-9.

14. Agarwal V, Mehrotra N, Vijay V. Gingival biotype assessment: variations in gingival thickness with regard to age, gender, and arch location. Indian J Dental Sci. 2017;9(1):12.

15. Fischer KR, Grill E, Jockel-Schneider Y, Bechtold M, Schlagenhauf U, Fickl S. On the relationship between gingival biotypes and supracrestal gingival height, crown form and papilla height. Clin Oral Implants Res. 2014;25(8): 894-8.

16. Olssoin $\mathrm{M}$, Lindhe J, Marinello C. On the relationship between crown form and clinical features of the gingiva in adolescents. J Clin Periodontol. 1993; 20(8):570-7.

17. Marinello CP, Meyenberg $\mathrm{KH}$, Zitzmann $\mathrm{N}$, Lothy $\mathrm{H}$, Soom U, Imoberdorf $\mathrm{M}$. Single-tooth replacement: some clinical aspects. J Esthet Restor Dent. 1997; 9(4):169-78.

18. Zawawi KH, Al-Harthi SM, Al-Zahrani MS. Prevalence of gingival biotype and its relationship to dental malocclusion. Saudi Med J. 2012;33(6):671-5.

19. Kydd W. The thickness measurement of masticatory mucosa in vivo. Int Dent J. 1971:21:430-41.

20. Wara-aswapati N, Pitiphat W, Chandrapho N, Rattanayatikul C, Karimbux N. Thickness of palatal masticatory mucosa associated with age. J Periodontol. 2001;72(10):1407-12

21. Vandana K, Savitha B. Thickness of gingiva in association with age, gender and dental arch location. J Clin Periodontol. 2005:32(7):828-30.

22. Geron S, Atalia W. Influence of sex on the perception of oral and smile esthetics with different gingival display and incisal plane inclination. Angle Orthod. 2005;75(5):778-84

23. Ainamo A, Ainamo J, Poikkeus R. Continuous widening of the band of attached gingiva from 23 to 65 years of age. J Periodontal Res. 1981;16(6): 595-9.

24. Chang L-C. The central papilla height in association with age and genderassessed with a new method. Chinese J Periodontol. 2006:11(3):272-9.

25. Chang LC. The association between embrasure morphology and central papilla recession. J Clin Periodontol. 2007;34(5):432-6.

26. Chen M-C, Chan C-P, Tu Y-K, Liao Y-F, Ku Y-C, Kwong L-K, et al. Factors influencing the length of the interproximal dental papilla between maxillary anterior teeth. J Dental Sci. 2009:4(3):103-9.

27. Kan JY, Rungcharassaeng K, Umezu K, Kois JC. Dimensions of peri-implant mucosa: an evaluation of maxillary anterior single implants in humans. J Periodontol. 2003;74(4):557-62

28. Chow YC, Eber RM, Tsao YP, Shotwell $\Perp$ L, Wang HL. Factors associated with the appearance of gingival papillae. J Clin Periodontol. 2010;37(8):719-27.

\section{Publisher's Note}

Springer Nature remains neutral with regard to jurisdictional claims in published maps and institutional affiliations.

Ready to submit your research? Choose BMC and benefit from:

- fast, convenient online submission

- thorough peer review by experienced researchers in your field

- rapid publication on acceptance

- support for research data, including large and complex data types

- gold Open Access which fosters wider collaboration and increased citations

- maximum visibility for your research: over $100 \mathrm{M}$ website views per year

At BMC, research is always in progress.

Learn more biomedcentral.com/submissions 